\title{
EXTERNAL EAR; \\ A MORPHOMETRIC STUDY AMONGST STUDENTS OF NAWAZ SHARIF MEDICAL COLLEGE GUJRAT
}

1. Assistant Professor of Anatomy, Nawaz Sharif Medical College, University of Gujrat.

2. Assistant Professor of

Orthopediac Surgery.

Nawaz Sharif Medical College, University of Gujrat.

3. Professor of Anatomy, Nawaz Sharif Medical College, University of Gujrat.

Correspondence Address:

Dr. Muhammad Umar

Assistant Professor of Anatomy,

N.S.MC, Gujrat.

drmumar@live.com

Article received on:

08/12/2016

Accepted for publication:

$15 / 03 / 2017$

Received after proof reading:

06/05/2017

\section{Dr. Muhammad Umar', Dr. Sajjad Rasoul Chaudhary², Dr. Muhammad Habib ur Rehman ${ }^{3}$}

ABSTRACT... Objectives: To determine morphometric measurements of external ear among medical students of Nawaz Sharif Medical College, University of Gujrat. Study Design: Cross sectional. Setting: This study was done among students of First \& Second year MBBS classes at Nawaz sharif Medical College, University of Gujrat. Period: 2015. Methodology: The study group consisted of 120 girls and 80 boys with age range 18 to 22 (median 20). Total Ear height, lobular height, lobular width and distances of helical root and insertion of the lobule from the lateral palpebral commissure were measured by using vernier caliper. Results: With analysis of normative cross-sectional data, this study endeavors to show anatomic and aesthetic differences between boys and girls. The average total ear height across the study group for both left and right ears was $6.50 \mathrm{~cm}$. The average lobular height was $1.9 \mathrm{~cm}$. The average lobular width was $2 \mathrm{~cm}$. The height of the pinna was significantly larger in boys than girls. The distance between helical root and lateral palpebral commissure was significantly larger among boys as compared to girls. The average height and width of the lobule of boys and girls were statistically insignificant.

Key words:

Article Citation: Umar M, Chaudhary SR, Habib ur Rehman M. External ear; a morphometric study amongst students of Nawaz Sharif Medical College, Gujrat. Professional Med J 2017;24(5):778-780. DOI: 10.17957/TPMJ/17.3769

\section{INTRODUCTION}

The visible part of external ear is called as pinna or auricle. The pinna projects from the side of the head. Its outer surface is irregularly concave, faces slightly forward and displays numerous eminences and depressions. The upper surface of pinna presents elevations that correspond to the depressions on its outer surface (Standring, 2008). ${ }^{1}$ The pinna possesses a skeleton of elastic cartilage covered by skin, which is thrown into folds that gives its characteristic shape. The lobule is a tag of skin containing soft fibro fatty tissue (Sinnatamby, 2000). ${ }^{2}$ The primary function of pinna is to collect sound waves that are transmitted to ear drum through external auditay meatus. Pinna is important anatomical land mark and it attributes greater part of natural beauty of face. Its structure shows signs of age and sex of an individual. ${ }^{1,2}$ Morphometric measurements of pinna are important for plastic surgeon for reconstructive surgery. ${ }^{3,4}$ It is important for forensic experts for personal identity. It is also important for anatomists for research.
The Morphometric measurements of the pinna have been reported in different ethnic groups: Brucker et al. (2003) described dimensions of pinna among American population and reported age- and sex-related differences. ${ }^{5}$ Bozkir et al. $(2006)^{6}$, Kalcioglu et al. (2003) ${ }^{7}$ and Barut and Aktunc $(2006)^{8}$ studied the pinnas of Turkish population. Purkait and Singh $(2007)^{9}$ examined the auricles of adult Indian peoples. Wang et al. $(2011)^{10}$ measured the auricles of Han Chinese population. Azaria et al. $^{3}$ (2003) studied the earlobes of an Israeli population. Gualdi-Russo (1998) ${ }^{11}$, Ferrario et al. ${ }^{12}$ (1999) and Sforza et al. $(2009)^{13}$ conducted morphological studies of external ear in Italy. Ekanem et al. (2010) 14 conducted an anthropometric study of the pinna in Nigeria. There is no such detail study of morphometric measurements of external ear among Pakistani population. Therefore, the current study was aimed to determine morphometric measurements of external ear among Pakistani population (MBBS students of Nawaz Sharif Medical College Gujrat). 


\section{MATERIALS AND METHOD}

This was cross sectional study that was performed in Anatomy Dept. in 2015. Various ear measurements were calculated by vernier caliper. The study group consisted 200 students of MBBS, First \& second years of Nawaz sharif Medical College, University of Gujrat. Age and sex of each student were recorded. The cohort consisted of 70 boys with age range 18 to 22 (median 20) and 130girls with age range 18 to 22 (median 20).

Following measurements were taken directly from each ear of the students by digital vernier caliper.

Total ear height (TEH): Distance between the highest point of the auricle and the lowest point of the ear lobe.

- Total ear width (TEW): Distance between the most anterior and posterior points of the ear

- Lobular height (L.H): Distance from the intertragic incisure to the caudal part of the lobule.

- Lobular width: Horizontal width of the lobule at the midpoint of the lobular height (Fig. 2).

- Distance from the tragus to the antihelix.

- Distance from the tragus to the helix.

Statistical analysis of various measurements was performed. Student's t-test was used to evaluate various measurements difference between male and female students.

\section{RESULTS}

The average total ear height among boys and girls was $6.30 \mathrm{~cm}$ and $5.8 \mathrm{~cm}$ respectively. The average lobular height among boys and girls was $1.96 \mathrm{~cm}$ and $1.88 \mathrm{~cm}$ respectively. The average lobular widths among boys and girls were $1.8 \mathrm{~cm}$ and $1.6 \mathrm{~cm}$ respectively. Theses measurements was statistically significant p.value $<0.05$. The average height of the pinna, calculated by subtracting the lobular height from the total ear height among boys and girls was $4.43 \mathrm{~cm}$ and $4.13 \mathrm{~cm}$ that is statistically significant (p.value $<0.05$ ).

The distance between helical root and lateral palpebral commissure was significantly larger among boys as compared to girls.

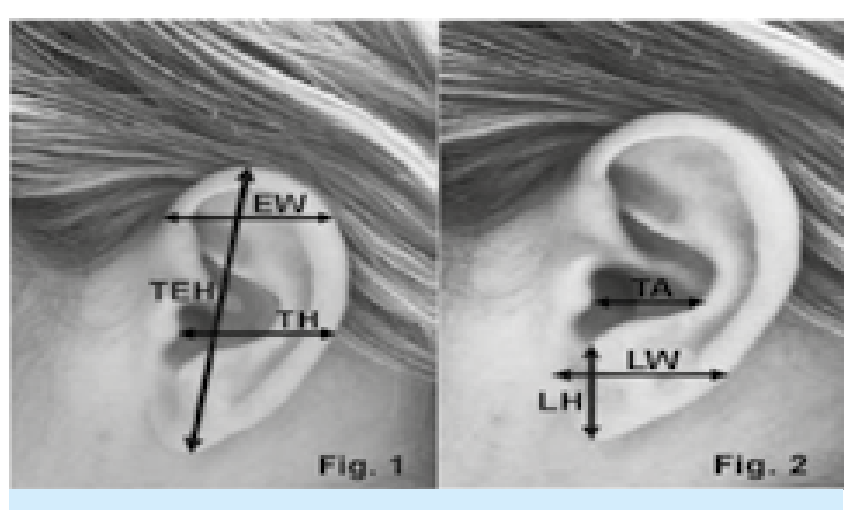

Figures. Various measurements of Ear

\section{DISCUSSION}

The external ear is an important anatomical land mark. Its size and shape give value able information regarding age and sex of person. The data generated from this study provides important information to forensic experts and surgeons like plastic surgeons and E.N.T Surgeons.

McKinney et.al. in 1993. ${ }^{15}$ studied morphometeric and morphological aspects of external ear with reference to aesthetic surgery. Our various measurements of external ears are in accordance with the findings of McKinney et.al. McKinney did not, however, find a significant correlation between earlobe height and aging. No analysis between male and female volunteers was reported.

Our data clearly suggests that earlobe size does not vary significantly between boys and girls. While total ear size is larger in boys, their earlobe height and width remain nearly identical to girls in our study group. When our data was analyzed for gender changes, there was statistically significant increase in Total ear height in boys as compared to girls.

This study concluded that the height of the pinna was significantly larger in boys than girls, while the distance between helical root and lateral palpebral commissure was significantly larger among boys as compared to girls. However, the average height and width of the lobule of boys and girls were statistically insignificant.

Copyright ( 15 Mar, 2017. 


\section{REFERENCES}

1. Standring S. (2008). Gray Anatomy. 40 th ed. Churchill Livingstone: New York. p. 649-52.

2. Sinnatamby C.S. (2000). Last's Anatomy, Regional and Applied. 10 th ed. Churchill Livingstone: New York. p. 340.

3. Azaria R., Adler N., Silfen R., Regev D., Hauben D.J. (2003). Morphometry of the adult human earlobe: A study of $\mathbf{5 4 7}$ subjects and clinical application. Plast Reconstr Surg 111 (7): 2398-402.

4. Brent, B. Reconstruction of the Auricle. In McCarthy, J.G. (Eds.), Plastic Surgery: The Face, Vol 3, Philadelphia: W. B. Saunders Company, 1990, Pp. 2095- 2152.

5. Brucker MJ, Patel J, Sullivan PK: A morphometric study ofthe external ear: Age and sex-related differences. Plast Reconstr Surg 112:647_652, 2003.

6. Bozkir M.G., Karakas P., Yavuz M., Dere F. (2006). Morphometry of the external ear in our adult population. Aesth Plast Surg 30 (1): 81-5.

7. Kalcioglu M.T., Miman M.C., Toplu Y., Yakinci C., Ozturan O. (2003). Anthropometric growth study of normal human auricle. Int J Pediatr Otorhinolaryngol 67 (11): 1169-77.

8. Barut C., Aktunc E. (2006). Anthropometric measurements of the external ear in a group of Turkish primary school students. Aesthet Plast Surg
30 (2): 255-9.

9. Purkait R., Singh P. (2007). Anthropometry of the normal human auricle: A study of adult Indian men. Aesthetic Plast Surg 31 (4): 371-9.

10. Wang B., Dong Y., Zhao Y., Shizhu Bai S., Wu G. (2011). Computed tomography measurement of the auricle in Han population of north China. J Plast Reconstr Aesthetic Surgery 64 (1): 34-40.

11. Gualdi-Russo E. (1998). Longitudinal study of anthropometric changes with aging in an urban Italian population. Homo 49: 241-59.

12. Ferrario V.F., Sforza C., Ciusa V., Serrao G., Tartaglia G.M. (1999). Morphometry of the normal human ear: A cross-sectional study from adolescence to midadulthood. J Craniofac Genet Dev Biol 19 (4): 226-33.

13. Sforza C., Grandi G., Binelli M., Tommasi D.G., Rosati R., Ferrario V.F. (2009). Age- and sex-related changes in the normal human ear. Forensic Sci Int 187 (1): 110. e1-7.

14. Ekanem A.U., Garba S.H., Musa T.S., Dare N.D. (2010). Anthropometric study of the pinna (Auricle) among adult Nigerians resident in Maiduguri metropolis. $J$ Med Sci 10 (6): 176-80.

15. McKinney P., Giese S., Placik O. (1993). Management of ear in rhytidectomy. Plast Reconstr Surg 92 (5): 85866.

\section{AUTHORSHIP AND CONTRIBUTION DECLARATION}

\begin{tabular}{|c|c|c|c|}
\hline Sr. \# & Author-s Full Name & Contribution to the paper & Author $=\mathbf{s}$ Signature \\
\hline 1 & Dr. Muhammad Umar & $\begin{array}{l}\text { Original data collection \& } \\
\text { research was done by first author }\end{array}$ & anal \\
\hline 2 & Dr. Sajjad Rasoul Ch. & $\begin{array}{l}\text { Second author helped in literature } \\
\text { review }\end{array}$ & \\
\hline 3 & Dr. M. Habib ur Rehman & $\begin{array}{l}\text { The third author helped in data } \\
\text { collection and analysis }\end{array}$ & \\
\hline
\end{tabular}

